\title{
Association between intestinal helminthiasis and serum ferritin levels among school children
}

\author{
Olufunmilayo Victoria Adebara ${ }^{1}$, Samuel Kolade Ernest ${ }^{2 *}$, Isaac Ayodele Ojuawo ${ }^{2}$ \\ ${ }^{1}$ Federal Medical Centre, Iddo-Ekiti, Nigeria; \\ ${ }^{2}$ Department of Paediatrics and Child Heath, University of Ilorin, Ilorin, Nigeria. \\ E-mail: *kolade.ernest@yahoo.com
}

Received 10 April 2011; revised 24 May 2011; accepted 16 June 2011.

\begin{abstract}
Background: significant iron deficiency anaemia is a major concern in children with helminthiasis, because it may eventually contribute to the growing health challenges of severe anaemia. This descriptive cross sectional study was carried out to determine the association between serum ferritin levels and intestinal helminthiasis among school children. Methods: a structured questionnaire was used to collect the study population data. Stool specimens were obtained and examined on the same day using the sedimentation method for identification of the parasite. Blood samples were also obtained for full blood count and serum ferritin measurement. Results: a total of 246 school children were studied with a response rate of $82 \%$. The prevalence of intestinal helminthiasis was $29.7 \%$. The different helminthes identified included Ascaris lumbricoides, Necator americanus, Trichuris trichiura, Strongyloides stercoralis. Of the population studied, $\mathbf{3 6 . 2} \%$ were anaemic, $\mathbf{1 5 . 9 \%}$ had microcytosis, and $47.6 \%$ had hypochromia. The prevalence of exhausted iron stores was $3.7 \%$. Serum ferritin levels were significantly lower in children with intestinal helminthiasis compared with controls. Conclusions: The findings in this study demonstrate an inverse relationship between intestinal helminthiasis and serum ferritin levels and this is more marked in pupils with hookworm infections. The control of intestinal helminthiasis and prevention of iron deficiency anaemia should be given high priority in the implementation of the school health programme.
\end{abstract}

Keywords: Intestinal Helminthiasis; Serum Ferritin; School Children

\section{INTRODUCTION}

Children are generally at risk of iron deficiency since the iron requirements for growth are high and the intake of iron is likely to be less than their requirements. Thus, any condition that increases the need for iron, decreases its intake or increases its loss will precipitate its deficiency [1].

Several factors contribute to iron deficiency such as insufficient dietary intake, malabsorption and infections [2]. Helminthic infections may influence iron status by reducing nutrient intake and by interfering directly or indirectly with iron metabolism and transport [2]. In school-aged children, both infections and iron deficiency can lead to anorexia. Infections inhibit the absorption of iron from the gastro-intestinal tract and iron deficiency lowers resistance to infections. This process creates a vicious circle of inadequate nutrition $[2,3]$.

Iron deficiency is very common in Nigeria, occurring in approximately $36 \%$ of children younger than 5 years of age [4]. Helminthiasis is also a common problem among Nigerian school children and has a negative impact in their physical and mental development by many mechanisms including malabsorption [6] blood and protein loss [7], anorexia, vomiting and diarrhoea. These effects can lead to aggravation of protein energy malnutrition [8], anemia and other nutrient deficiencies [8] (iodine, vitamin A, iron deficiency) [9] which indirectly affect cognitive development and performance. Iron deficiency impairs children's cognitive abilities, and interventions to prevent and correct iron deficiency may enhance children's learning potential in school $[5,6]$. Improving the iron status of school children will also ameliorate their fitness and work capacity [11], and improvements in girls' iron status during the school age may help prevent anemia during their reproductive years.

The school setting is ideal for public health interventions, such as health education, iron supplementation and treatment or prevention of parasitic infestations [12] The aim of this study was to study the association of helminthic infections and serum ferritin among school children. 


\section{MATERIALS AND METHODS}

The study was a descriptive cross sectional study conducted over a four month period in Ilorin metropolis, a typical urban city in the middle belt of Nigeria. The town has pipe-borne water that is supplied erratically on some days of the week with augmentation from other sources such as well, streams and bore-holes. Most of the homes have pit latrines and water closets used by both the adults and children [13]. There are 98 public schools and 71 private schools within Ilorin metropolis; a few have school clinics managed by nurses or trained teachers that can offer first aid treatment [13].

The study population consisted of primary school children aged between 5 and 12 years from 3 private sand 3 public schools Children who had taken antihelminthic drugs within 6 months of study or those who received a blood transfusion or iron containing medicines within 3 months preceding the study or those who were febrile were excluded.

Multistage sampling technique was employed in selecting subjects for this study. Selection of schools was done by a simple random sampling technique. Selection of classes in each school was done by a proportionate sampling technique. Selection of pupils was done by a: systematic random sampling. Controls of the study were age and sex matched children without helminthiasis.

A structured questionnaire was used to collect sociodemographic characteristics such as age, sex, level of education of the parents and socieconmic status. Anthropometric measurements (i.e., weights and heights) were performed.

Fresh stool sample was collected using precoded specimen bottles. Samples were analyzed within an hour of collection or preserved using $10 \%$ formol saline when immediate analysis was not possible. However, all analysis was done within 24 hours. Each stool sample was microscopically examined using saline and iodine preparations and formyl ether for the identification of the parasite species $[14,15]$.

Under strict aseptic conditions a $5 \mathrm{ml}$ specimen of venous blood was withdrawn. $3 \mathrm{ml}$ of the blood was decanted into a sample bottle containing ethylene diamine tetra acetate (EDTA) and gently mixed to prevent clotting while the remaining $2 \mathrm{ml}$ was decanted into a heparinized bottle which was to stand for 2 hours and the serum was separated into another bottle and stored frozen at $-20^{\circ} \mathrm{C}$.

Hemoglobin concentration was determined using a Sysmex 18 parameter autoanalyser. Anaemia was defined as a hemoglobin of less than $11 \mathrm{~g} / \mathrm{dl}$ and severe anaemia was defined as an haemoglobin of less than 5 $\mathrm{g} / \mathrm{dl}$ [16]. Serum ferritin concentration was analyzed by enzyme-linked immunoadsorbent assay using the CLI-
NOTECH $^{\circledR}$ human ferritin enzyme immunoassay test kit. [17] Exhaustion of iron stores was defined as a serum ferritin of less than $20 \mu \mathrm{g} / \mathrm{L}$.

Data entry and analysis were carried out with the Epi info version 6.0 software for epidemiology developed by Centers for Disease Control and Prevention [18]. A $p$-value of less than 0.05 was considered as significant.

\section{RESULTS}

A total of 300 primary school children from 6 selected schools were recruited into the study but 246 (82\%) returned with suitable stool and blood specimens. The characteristics of these children are presented in Table 1. The overall prevalence rate of intestinal helminthic infections was $29.7 \%$. In addition, $26.5 \%$ of the males and $31.9 \%$ of females had parasitic infections (Table 1). The mean age, weight and height according to sex are summarized in Table 2.

Anaemia was recorded in $36.2 \%$ of the pupils studied. No pupil had severe anaemia. Serum ferritin in the total population studied was $77.6 \pm 32.6 \mu \mathrm{g} / \mathrm{L}$. Serum ferritin of less than $20 \mu \mathrm{g} / \mathrm{L}$ (iron stores exhaustion) was observed in $3.7 \%$ of the studied population. Serum ferritin in males was $72.0 \pm 29.9 \mu \mathrm{g} / \mathrm{L}$ compared to $83.2 \pm 35.4 \mu \mathrm{g} / \mathrm{L}$ in females $(p=0.01)$. Serum ferritin, did not differ significantly in pupils in the various age-groups (Table 3). Serum ferritin levels were significantly lower in children with intestinal helminthiasis compared with controls. However there was no significant difference in total protein and serum albumin levels between the groups (Table 4).

Table 1. The sex distribution of pupils according to age in the total population studied.

\begin{tabular}{cccccc}
\hline $\begin{array}{c}\text { Age } \\
\text { years })\end{array}$ & $\begin{array}{c}\text { Total } \\
n(\%)\end{array}$ & $\begin{array}{c}\text { Male } \\
n(\%)\end{array}$ & $\begin{array}{c}\text { Female } \\
n(\%)\end{array}$ & $\begin{array}{c}\text { Odd } \\
\text { Ratio }\end{array}$ & $p$ \\
\hline $5-7$ & $67(27.2)$ & $22(21.6)$ & $45(31.3)$ & 1.65 & NS \\
$8-10$ & $116(47.2)$ & $49(48.0)$ & $67(46.5)$ & 0.94 & NS \\
$11-12$ & $63(25.6)$ & $31(30.4)$ & $32(22.2)$ & 0.65 & NS \\
Total & 246 & $102(41.5)$ & $144(58.5)$ & & NS \\
\hline
\end{tabular}

Table 2. The mean age, weight and height according to sex.

\begin{tabular}{ccccc}
\hline & Male & Female & T & $p$ \\
& $n=102$ & $n=144$ & & NS \\
\hline Age (yrs) & $9.2 \pm 2.07$ & $8.7 \pm 2.18$ & 1.7 & NS \\
Weight $(\mathrm{kg})$ & $23.4 \pm 5.7$ & $23.2 \pm 6.4$ & 0.3 & NS \\
Height $(\mathrm{cm})$ & $121.5 \pm 11.23$ & $120.07 \pm 12.85$ & 0.87 & \\
\hline
\end{tabular}

NS: no significant

Table 3. Ferritin levels amongst the different age-groups in the population of the study.

\begin{tabular}{ccc}
\hline & \multicolumn{2}{c}{ Serum ferritin $(\mu \mathrm{g} / \mathrm{L})$} \\
\hline Age-group (years) & Mean & Range \\
$5-7$ & $74.12 \pm 34.13$ & $15-140$ \\
$8-10$ & $75.78 \pm 33.66$ & $5-150$ \\
$11-12$ & $83.69 \pm 32.96$ & $20-150$ \\
\hline
\end{tabular}

$F=1.02 ; p=$ NS; NS: no significant 
Table 4. Comparison of serum ferritin, serum protein and serum albumin levels in the infected and non-infected groups.

\begin{tabular}{ccccc}
\hline & $N$ & $\begin{array}{c}\text { Serum Ferritin } \\
(\mu \mathrm{g} / \mathrm{L})\end{array}$ & $\begin{array}{c}\text { Total Protein } \\
(\mathrm{g} / \mathrm{L})\end{array}$ & $\begin{array}{c}\text { Serum albumin } \\
(\mathrm{g} / \mathrm{L})\end{array}$ \\
\hline Non-infected & 173 & $83.6 \pm 36.56$ & $66.3 \pm 0.92$ & $35.17 \pm 0.52$ \\
Infected & 73 & $72.4 \pm 25.26$ & $65.8 \pm 0.90$ & $35.63 \pm 0.52$ \\
\hline
\end{tabular}

$F=5.7 ; p=0.01 ; p=\mathrm{NS} ; p=\mathrm{NS} ; \mathrm{NS}$ : no significant

Table 5. Comparison of the serum ferritin levels of the non infected group with the levels of children with different intestinal helminthes.

\begin{tabular}{cccc}
\hline & \multicolumn{3}{c}{ Serum ferritin levels } \\
& Mean \pm SD & F & $p$ \\
\hline Non-infected: & $83.6 \pm 36.56$ & & \\
Helminth detected: & & & \\
Ascaris lumbricoides & $81.9 \pm 30.91$ & 0.1 & $\mathrm{NS}$ \\
Hookworm species & $50.9 \pm 27.91$ & 8.47 & $\mathrm{NS}$ \\
Trichuris trichiura & $66.7 \pm 14.43$ & 0.64 & $\mathrm{NS}$ \\
Polyparasites & $72.5 \pm 53.03$ & 0.35 & $\mathrm{NS}$ \\
Strongyloides stercoralis & $90.00 \pm 0.00$ & 2.43 & 0.04 \\
\hline
\end{tabular}

NS: no significant

In Table 5 the results of the serum ferritin levels with different intestinal helminthes are presented and are compared with those of the control group. It is of interest that 4 of 11 patients $(36 \%)$ of patients with hookworm infection had exhausted iron stores.

\section{Discussion}

This study showed an overall prevalence of $29.7 \%$ of the common intestinal helminthic infections among primary school children in Ilorin. This value is comparable to the findings of similar studies in other parts of Nigeria [19-22] and Africa [23]. While higher prevalence rates of between $50 \%$ and $97 \%$ [24-30] as well as lower prevalence rates of less than $20 \%$ [23,31-34] have been reported. These differences in the prevalence rates could be attributable to the locations of the studies, the season of the year the study was carried out and the method of stool analysis. The high prevalence rate in this study therefore confirms that intestinal helminthic infection is a common problem in the school aged children.

In this study, the female children had a higher prevalence of intestinal helminthic infections prevalence than the males. This is in consonance with studies previously documented $[34,35]$. The influence of gender on prevalence of helminthic infection may or may not play a role depending on the regional and environmental factors.

The overall prevalence rate of anaemia among the school children studied was high. More than a third of the pupils had their haemoglobin levels less than $11 \mathrm{~g} / \mathrm{dl}$. It is noteworthy to state that no pupil had severe anaemia. This is in consonance with previous publications [16]. The mean haemoglobin value is higher than values obtained in previous studies [36-39]. Childhood anaemia appears to be increasing in the country due to the declining nutritional status secondary to a dwindling national economy.

In this study, a comparison of the haematological status between the intestinal helminthic-infected and non-infected children showed that the mean haemoglobin indices of the latter were higher.

The iron store of the population in this study was adequate with only $3.7 \%$ having exhausted iron stores. This is at variance with studies done in other parts of Africa [2,3] where the degree of exhausted iron stores were high. This could be attributed to the low prevalence of hookworm infection observed. The serum ferritin level was higher in females than males. This has also been documented in a previous study [3]. The reason for this could be attributed to the higher number of boys infected with hookworm species. The serum ferritin level was higher in pupils aged 10 years and above and lower at the age of 8 years. This is in agreement with previously documented studies where it was attributed to the high iron demands of early childhood $[2,3]$.

The serum ferritin levels were lower in children with hookworm infection. In addition, $36 \%$ of pupils with hookworm had exhausted iron stores. No relationship was found between Ascaris lumbricoides and iron status in this study. This is similar to the study done in Western Kenya but not with that done in Zanzibar, where low serum ferritin levels were associated with Ascariasis. Iron is absorbed through the intestinal wall in the duodenum and jejunum and it is believed that iron absorption could be impaired by the presence of Ascaris lumbricoides in this part of the intestine [40]. Trichuris trichiura infection was not related to any of the iron status indicators. This is because Trichuris trichiura lives in the luminal epithelium, mainly the large intestine, and trichuriasis has a specific association with anaemia which is mediated through erythrocyte loss from the gut [41].

The high prevalence of intestinal helminthic infection and anaemia observed in this study calls for a comprehensive public health intervention. The most important application of the findings is to guide the development of appropriate interventions to minimize the predisposing factors to parasitic infections and prevent iron deficiency anaemia in school children. There is a strong basis for helminthics control as a strategy to control iron deficiency in the population group. Antihelminthic drugs are safe and cheap and periodic delivery of these drugs through the school system is a highly feasible public health intervention [42].

\section{REFERENCES}

[1] Schwartz, E. (2000) Iron deficiency anaemia. In: Behrman, R.E., Kliegman, R.M. and Jenson, H.B., Eds., Nelson 
Textbook of Paediatrics, W.B. Saunders Company, Philadelphia, 1469-1471.

[2] Olsen, A., Magnussen, P., Ouma, J.H. and Friis, H. (1998) The contribution of hookworm and other parasitic infections to haemoglobin and iron status among children and adults in western Kenya. The Transactions of the Royal Society of Tropical Medicine and Hygiene, 92, 643-649. doi:10.1016/S0035-9203(98)90795-7

[3] Stoltzfus, R.J., Chwaya, H.M., Tielsch, J.M. and Schulze, K.J. (1997) Epidemiology of iron deficiency anaemia in Zanzibar schoolchildren: The importance of hookworms. The American Journal of Clinical Nutrition, 65, 153-159.

[4] Maziya-Dixon, B., Sanusi, R.A., Akinyele, I.O. and Oguntona, E.B. (2004) Iron status of children under 5 in Nigeria: Results of the Nigeria food consumption and nutrition survey. Proceedings of Iron Deficiency in Early Life and Challenges and Progress, Lima, 18 November 2004, 43.

[5] Hendrickse, R.G. (1991) Disorders of the blood. In: Hendrickse, R.G., Barr, D.G.D., Matthews and T.S., Eds., Paediatrics in the Tropics, Blackwell Scientific Publications, London, 336-372.

[6] Adedoyin, M.A., Awogun, I.A. and Juergensen, T. (1990) Prevalence of intestinal parasitoses in relationship to diarrhea among children in Ilorin. West African Journal of Medicine, 9, 83-88.

[7] Montressor, A., Cromptom, D.W.T., Gyorkos, T.W. and Savioli, L. (2002) Helminthic control in school aged children. A guide for managers of control programme. WHO, Geneva, 1.

[8] Ikpeme, E. and Anochie, K. (1999) Intestinal helminthic infestations. In: Azubuike J.C. and Nkanginieme, K.E.O. Eds., Pediatrics and Child Health in a Tropical Region, African Educational Services, Port Harcourt, 438-444.

[9] Bundy, D.A.P., Hall, A., Adjei, S., Kihama, C. and Khoi, H.H. (1997) Better health, nutrition and education for the school aged child. The Transactions of the Royal Society of Tropical Medicine and Hygiene, 91, 1-2. doi:10.1016/S0035-9203(97)90370-9

[10] Hass, J.D. and Fairchild, M.W. (1989) Summary and conclusions of the international conference on iron deficiency and behavioural development. American Journal of Clinical Nutrition, 50, 703-705.

[11] Stephenson, L.S., Latham, M.C., Adams, E.J. Kinoti, S.N. and Pertet, A. (1993) Physical fitness, growth and appetite of Kenyan school boys with hookworm, tricuris trichiura and ascaris lumbricoides infections are improved four months after a single dose of Albendazole. Journal of Nutrition, 123, 1036-1046.

[12] Savioli, L., Bundy, D.A.P. and Tomkins, A. (1992) Intestinal parasitic infections: A soluble public health problem. The Transactions of the Royal Society of Tropical Medicine and Hygiene, 86, 353-354. doi:10.1016/0035-9203(92)90215-X

[13] Jimoh, L.A.K. (1994) Present day Ilorin. In: Ilorin: The Journey So Far, Atoto Press Limited, Ilorin, 8-11.

[14] Cheesbrough, M. (1998) District laboratory practice in tropical countries. Part 1. Tropical health technology. Tropical Health Technology, Norfolk, 192-196.

[15] Markell, E.K. (1992) Examination of stool specimen. In: Markell, E.K., Voge, M. and John, D.T. Eds, Medical Parasitology, W.B. Saunders Company, Philadelphia,
406-428.

[16] Adewuyi, J.O. (1992) Current prevalence and some clinical associations of childhood anaemia in urban communities in central Nigeria. Central African Journal of Medicine, 38, 66-72.

[17] Fairbanks, V.F. and Klee, G.G. (1999) Biochemical aspects of haematology. In: Tietz Textbook of Clinical Chemistry, W.B. Saunders Company, Philadelphia, 1703-1704.

[18] Dean, A.G. and Dean, J.A., Coulombier, D., et al. (1995) Epi info version 6.0: A word processing data base and statistics programme for public health on IBMCompatible micro computers. Center for Disease Control and Prevention, Atlanta.

[19] Ighogboja, I.S. and Ikeh, E.I. (1997) Parasitic agents in childhood diarrhea and malnutrition. West African Journal of Medicine, 16, 21-25.

[20] Okafor, C.N. and Azubike, C.N. (1992) Studies in intestinal parasitic disease agents in stools of people in a rural area in Nigeria. West African Journal of Medicine, 11, 106-111.

[21] Agi, I.P. (1997) Comparative helminth infection of man in two rural communities of the Niger delta, Nigeria. West African Journal of Medicine, 16, 232-236.

[22] Fashuyi, S.A. (1992) The pattern of human intestinal helminth infection in farming communities in different parts of Ondo State, Nigeria. West African Journal of Medicine, 16, 102-105.

[23] Curtale, F., Pezzotti, P., Saad, Y.S. and Aloi, A. (1999) An analysis of individual, household and environmental risk factors for intestinal helminth infection among children in Qena Governate, Upper Egypt. Journal of Tropical Paediatrics, 45, 14-17. doi:10.1093/tropej/45.1.14

[24] Ibrahim, M., Odoemena, D.I. and Ibrahim, M.T. (2000) Intestinal helminthic infections among primary school children in Sokoto. Sahel Medical Journal, 3, 62-68.

[25] Omoigberale, A.I., Airauhi, L. and Ibadin, M.T. (1996) Intestinal helminthiasis amongst school children in Benin City, Nigeria. Nigerian Journal of Medicine, 30, 118-122.

[26] Meremikwu, M.M., Anita-Obong, O.E., Asindi, A.A. and Ejezie, G.C. (1995) Nutritional status of pre-school children: Relationship with intestinal helminthiasis. Nigerian Journal of Medicine, 4, 40-44.

[27] Runsewe-Abiodun, T.I., Olowu, A.O., Akosode, F.A. and Odetunde, O.S. (1995) Prevalence of helminthic infestation in pre-school children. Nigerian Journal of Paediatrics, 22, 81-82.

[28] Kabatereine, N.B., Tukahebwa, E.M., Brooker, S., Alderman, H. and Hall, A. (2001) Epidemiology of intestinal helminth infestations among school children in Southern Uganda. East African Medical Journal, 76, 283-286.

[29] De Carneri, I., Di Matteo, L. and Tedla, S. (1992) A comparism of helminth infection in urban and rural areas of Addis Ababa. The Transactions of the Royal Society of Tropical Medicine and Hygiene, 86, 540-541. doi:10.1016/0035-9203(92)90099-X

[30] Albonico, M., De Carneri, I., Di Matteo, L., Ghiglietti, R., Toscano, P., Uledi, M.K., et al. (1993) Intestinal parasitic infections of urban and rural children on Pemba Island: Implications for control. Annals of Tropical Medicine 
and Parasitology, 87, 579-583.

[31] Flores, A., Esteban, J., Angles, R. and Mas-Coma, S. (2001) Soil transmitted helminthic infections at very high altitude in Bolivia. The Transactions of the Royal Society of Tropical Medicine and Hygiene, 95, 272-277. doi:10.1016/S0035-9203(01)90232-9

[32] Gbakima, A.A., Sherpard, M. and White, P.T. (1994) Intestinal helminth infections in rural school children in Njala, Sierra Loene. East African Medical Journal, 71, 792-796.

[33] Phiri, K., Whitty, C.J.M., Graham, S.M. and SsembatyaLule, G. (2000) Urban/rural differences in prevalence and risk factors for intestinal helminth infections in Southern Malawi. Annals of Tropical Medicine and Parasitology, 94, 381-387.

[34] Musa, O.I. (1997) Intestinal Helminthiasis among students seen during school entrance medical examination in Ilorin. Journal of Community Medicine and Primary Health, 9, $35-41$.

[35] Elekwa, D.E. and Ikeh, E.I. (1996) A survey of the incidence of intestinal parasites amongst primary school children in relation to socio-economic factors in Jos, Nigeria. Nigerian Medical Practice, 31, 60-62.

[36] Azubike, J.C., Izuora, G.I. and Obi, G.O. (1977) Anaemia in nonsickling children around Enugu. Tropical and
Geograogical Medicine, 29, 365-268.

[37] Fleming, A.F. and Werbinska, B. (1982) Anaemia in childhood in the guinea savanna of Nigeria. Annals of Tropical Paediatrics, 2, 161-173.

[38] Akenzua, G.I., Ihongbe, J.C., Imasuen, V.I. and Mwobi, B.C. (1985) Anaemia on children: A survey in Obadan, a rural community in the rain forest zone of Nigeria. Journal of Tropical Paediatrics, 31, 20-24.

[39] Akinkugbe, F.M. (1977) Prevalence of anaemia in an urban population (University College Hospital GOPD). Journal of Tropical Paediatrics and Environmental Child Health, 23, 271-275.

[40] Islek, I., Kucukoduk, S., Cetinkaya, F. and Gurses, N. (1983) Effects of Ascaris infection on iron absorption in children. Annals of Tropical Medicine and Parasitology, 87, 477-481.

[41] Bundy, D.A.P. and Cooper, E.S. (1989) Trichuris and trichuriasis in humans. Advances in Parasitology, 28, 107-173. doi:10.1016/S0065-308X(08)60332-2

[42] Warren, K.S., Bundy, D.A.P. and Anderson, R.M. (1993) Helminth infection. In: Jamison, D.T., Mosley, W.H., Measham, A.R. and Bobadilla, J.L., Eds., Disease Control Priorities in Developing Countries, New York University Press, New York, 131-160. 